\title{
Oral Pharmacokinetics of Mirodenafil in Mexican Healthy Volunteers
}

\author{
Miriam del Carmen Carrasco-Portugal ${ }^{1}$, Francisco Javier Flores-Murrieta ${ }^{1,2}$, \\ Juan Gerardo Reyes-García ${ }^{2}$, Noemí Santos-Caballero ${ }^{3}$ \\ ${ }^{1}$ Unidad de Investigación en Farmacología, Insituto Nacional de Enfermedades Respiratorias “Ismael Cosio Villegas”, México DF, \\ México; ${ }^{2}$ Sección de Estudios de Posgrado e Investigación, Escuela Superior de Medicina, Instituto Politécnico Nacional, México DF, \\ México; ${ }^{3}$ Landsteiner Scientific, S.A. de C.V., México DF, México. \\ Email: nsantoscaballero@gmail.com, nsantos@landsteiner.com
}

Received November $22^{\text {nd }}, 2013$; revised December $25^{\text {th }}, 2013$; accepted January $9^{\text {th }}, 2014$

Copyright (C) 2014 Miriam del Carmen Carrasco-Portugal et al. This is an open access article distributed under the Creative Commons Attribution License, which permits unrestricted use, distribution, and reproduction in any medium, provided the original work is properly cited. In accordance of the Creative Commons Attribution License all Copyrights @ 2014 are reserved for SCIRP and the owner of the intellectual property Miriam del Carmen Carrasco-Portugal et al. All Copyright (C) 2014 are guarded by law and by SCIRP as a guardian.

\section{ABSTRACT}

Mirodenafil is a 5-phosphodiesterase inhibitor that is currently marketed in Korea for the treatment of erectile dysfunction; however, no information in other populations is available. It has been described that Mirodenafil is metabolized by CYP3A4, a metabolic pathway in which interethnic differences have been reported. The purpose of this study was to characterize the oral pharmacokinetics of Mirodenafil in Mexicans. Seventeen male healthy volunteers were enrolled in this study. After an overnight fast, volunteers received an oral $100 \mathrm{mg}$ dose and blood samples were collected at selected times during $24 \mathrm{~h}$. Plasma was stored frozen and analyzed by an HPLC method. Pharmacokinetic parameters obtained were: $C_{\max } 331.129 \pm 32.689 \mathrm{ng} / \mathrm{mL}, t_{\max } 1.574 \pm 0.293 \mathrm{~h}$, AUC $24 \mathrm{~h}$ 883.293 $\pm 104.088 \mathrm{ng} \cdot \mathrm{h} / \mathrm{mL}$, AUC $_{\infty} 976.477 \pm 108.812 \mathrm{ng} \cdot \mathrm{h} / \mathrm{mL}$ and $\mathrm{t}_{1 / 2} \mathbf{1 . 8 0 7} \pm 0.171 \mathrm{~h}$. Parameter values observed in this study are similar to those reported in Koreans. Since efficacy and safety studies of Mirodenafil have been conducted in Koreans, it is expected that dosage regime to employ in Mexicans should be similar to the approved for Korean population.

\section{KEYWORDS}

Erectile Dysfunction; Healthy Volunteers; Mexican; Mirodenafil; Pharmacokinetic

\section{Introduction}

Mirodenafil is a 5-phosphodiesterase (PDE-5) inhibitor that is useful in the treatment of erectile dysfunction [1]. PDE-5 inhibitors produce their effect by increasing cyclic guanosine monophosphate (cGMP), by an augment and long duration of vasodilatory activity of nitric oxide (NO) and prostaglandin I2 [2,3]. That is why PDE-5 inhibitors produce selective vasodilation in pulmonary artery, leading to a reduction of pulmonary blood pressure, with a transitory non clinically significant reduction of systemic blood pressure. Additionally, these drugs are able to potentiate the relaxation of smooth muscle of corpus cavernous, leading to penis erection in presence of sexual stimulus. During sexual stimulus, NO is pro- duced and released by endothelial cells and non-adrenergic, non-cholinergic nerves. PDE-5 inhibition produces a marked increase of cGMP in the corpus cavernous, leading to relaxation of smooth muscle and penis erection [2,3].

Pharmacokinetics of this drug has been evaluated in animal models and it has been established that this drug is metabolized by several pathways, including cytochrome P-450 3A (CYP3A4) [4-7]. Clinically, pharmacokinetics of this drug has been evaluated in Korean population [8-10]. It has been described that Mirodenafil is rapidly absorbed after oral dosing, reaching the maximal concentration in about 1.25 hours, food intake reduced the absorption of the drug, therefore, it is recommended to be ingested fasted. Mirodenafil is extensively bound to 
plasma proteins (97\%), and is metabolized by CYP3A4 to a metabolite 10 times less active. Half-life of Mirodenafil is about 2.5 hours.

Previously, our group reported that some drugs metabolized by CYP3A4, as nifedipine [11], cyclosporine [12], midazolam [13] sildenafil [14], among others, reach higher levels in Mexicans in comparison with Caucasians, but limited information are available when compared with Asian population. Therefore, in order to establish an adequate dosage regimen in Mexicans, it is important to establish if oral pharmacokinetics of Mirodenafil in our population is similar to the reported in Koreans, population in which efficacy and safety of Mirodenafil have been evaluated [1].

\section{Subjects and Methods}

\subsection{Subjects}

Seventeen Mexican male healthy subjects weighing (mean \pm S.D.) $72.36 \pm 8.40 \mathrm{Kg}$ with $1.66 \pm 0.08 \mathrm{~m}$ of height and $35.94 \pm 11.51$ years of age were included in the study. All subjects were fit according to medical examination, clinical history and suitable laboratory tests. Volunteers gave written informed consent for participation in the study, according to the protocol approved by the Institutional Ethics Committee. After an overnight fast, subjects received an oral dose of 100 mg Mirodenafil (a tablet) and blood samples were obtained immediately before and at $0.5,0.75,1,1.25,1.5,2,2.5,3,3.5$, 4, 5, 6, 8, 12 and 24 hours after drug administration. Plasma was obtained by centrifugation of blood samples and stored frozen at $-80^{\circ} \mathrm{C}$ until analyzed for Mirodenafil concentration.

\subsection{Determination of Mirodenafil in Plasma}

Mirodenafil plasma levels were determined by a highperformance liquid chromatographic (HPLC) method developed in our laboratory. Briefly, plasma samples (0.25 $\mathrm{mL}$ ) were placed in conical glass tubes and were added with $0.3 \mathrm{~mL}$ of $0.1 \%$ ammonium hydroxide in acetonitrile. Tubes were agitated at maximum speed in a vortex mixer for $1 \mathrm{~min}$ and centrifuged at $4500 \mathrm{rpm}$ for $10 \mathrm{~min}$. Then, upper layer was placed in autosampler vials and samples were filtered with Millipore membranes, then $100 \mu \mathrm{L}$ aliquots were injected into the chromatographic system.

The chromatographic system was Waters (Waters Associates, Milford, MA, USA) and was formed by a 2695 Alliance system, a 996 diode-array detector placed at 254 $\mathrm{nm}$. Separation of compounds was carried out in a 150 $\mathrm{mm} \times 4.6 \mathrm{~mm}$ of $5 \mu \mathrm{m}$ particle size Fortis C18 column, eluted with a mixture of $0.1 \%$ ammonium hydroxide in acetonitrile with water $(55: 45, \mathrm{v} / \mathrm{v})$. Flow rate was maintained constant at $0.8 \mathrm{~mL} / \mathrm{min}$. Retention time of Mirodenafil was 7.2 - $7.3 \mathrm{~min}$. Under these conditions, the method was linear in the range of 25 to $500 \mathrm{ng} / \mathrm{mL}$ and intra- and inter-day accuracy was between 89 and 105\% and coefficient of variation was lower than 9\%, making this method suitable for conducting pharmacokinetic studies of Mirodenafil.

\subsection{Pharmacokinetic Analysis}

Plasma concentration against time curves were plotted and maximal concentration $\left(\mathrm{C}_{\max }\right)$ and time to reach this maximum $\left(\mathrm{t}_{\max }\right)$ were directly obtained from these curves. Area under the plasma concentration against time curve until the last sampling time $\left(\mathrm{AUC}_{24}\right)$ was obtained by the trapezoidal rule. Area under the curve extrapolated to infinity $\left(\mathrm{AUC}_{\infty}\right.$ ) was obtained by the sum of $\mathrm{AUC}_{24}$ plus extrapolation to infinity, obtained by dividing the last concentration by the terminal elimination rate constant $\left(\mathrm{K}_{\mathrm{e}}\right)$. Half-life $\left(\mathrm{t}_{1 / 2}\right)$ was obtained by diving $\mathrm{Ln} 2 / \mathrm{K}_{\mathrm{e}}$. All parameters were obtained using the WinNonlin Professional ver. 2.1 software.

\section{Results}

Treatment with Mirodenafil was well tolerated. Mild reduction of blood pressure were observed in 10 volunteers, whereas, three subjects referred side effects, being headache ( 1 volunteer), nausea ( 1 volunteer) and sweltering (1 volunteer). Figure 1 shows the Mirodenafil chemical structure, whereas Figure 2 illustrates Mirodenafil representative chromatograms obtained with the blank, Mirodenafil spiked plasma (200 ng/mL) and patient's samples, in which the retention time of Mirodenafil was found around 7.2 - 7.3 min. Figure 3 depicts mean plasma concentration against time curve obtained in the seventeen subjects that received an oral $100 \mathrm{mg}$ dose of Mirodenafil in fasting conditions. Plasma levels are depicted until 8 hours, since no detectable concentration of Mirodenafil were observed after this time, indicating a rapid elimination rate of the compound (less than 2 hours). It can be seen that Mirodenafil is rapidly absorbed reaching the $\mathrm{C}_{\max }$ in about 1.5 hours. Individual pharmacokinetic parameters obtained are shown in Table 1. When parameters values obtained in Mexicans were compared with those values reported in Koreans, it was observed that similar values were observed, as shown in Table 2.

\section{Discussion}

Oral pharmacokinetics of Mirodenafil in Mexican healthy volunteers was evaluated and compared with previous studies conducted in Korean population. So far, no information about pharmacokinetics of Mirodenafil is available in other populations. Mirodenafil is metabolized by CYP3A4, and inte rethnic differences in the pharmacokinetics of drugs metabolized by this pathway have 
<smiles>CCCOc1ccc(S(=O)(=O)N2CCN(CCO)CC2)cc1-c1nc(=O)c2c([nH]1)c(CCC)cn2CC</smiles>

Figure 1. Chemical structure of Mirodenafil.

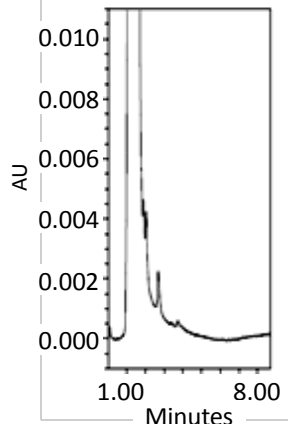

(a)

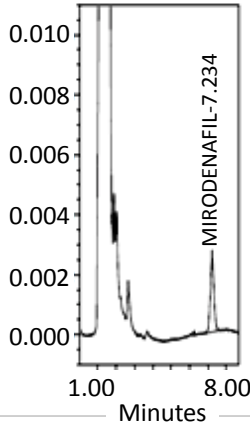

(b)

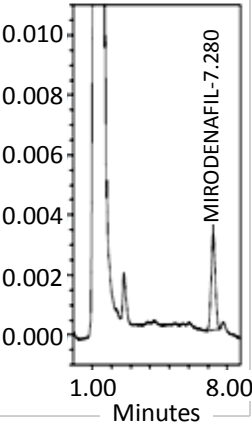

(c)
Figure 2. Representative chromatograms obtained with the blank (a), Mirodenafil spiked plasma (b) and patient's plasma samples (c).

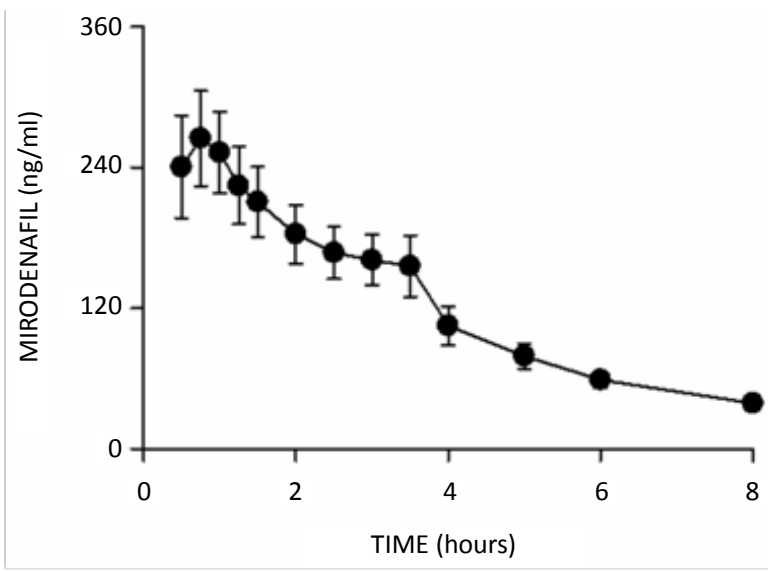

Figure 3. Plasma concentration-time curves of $100 \mathrm{mg}$ Mirodenafil in 17 Mexican healthy volunteers. Data are presented as mean \pm standard deviation.

been reported. In fact, it has been described that Mexican reach higher levels than the reported in Caucasians with drugs metabolized by this pathway, as midazolam, sildenafil, nifedipine, cyclosporine, among others [11-14]. However, limited information is available when data were compared with Asians. It has been observed that oral pharmacokinetics of nifedipine is similar in Asians in comparison with Mexicans [15]. Such differences in pharmacokinetics of drugs indicate that dosage regimes
Table 1. Individual pharmacokinetic parameters of Mirodenafil obtained after administration of an oral $100 \mathrm{mg}$ dose to seventeen healthy volunteers.

\begin{tabular}{|c|c|c|c|c|c|}
\hline Volunteer & $\begin{array}{c}\mathrm{C}_{\max } \\
(\mathrm{ng} / \mathrm{mL})\end{array}$ & $\begin{array}{l}\mathrm{t}_{\max } \\
\text { (h) }\end{array}$ & $\begin{array}{c}\mathrm{AUC}_{24} \\
(\mathrm{ng} \cdot \mathrm{h} / \mathrm{mL})\end{array}$ & $\begin{array}{c}\text { AUC } \infty \\
(\mathrm{ng} \cdot \mathrm{h} / \mathrm{mL})\end{array}$ & $\begin{array}{l}\mathrm{t}_{1 / 2} \\
\text { (h) }\end{array}$ \\
\hline 1 & 433.8 & 0.8 & 1598.9 & 1694.7 & 1.6 \\
\hline 2 & 374.4 & 1.3 & 867.2 & 919.0 & 1.4 \\
\hline 3 & 424.6 & 3.5 & 1043.7 & 1209.7 & 2.2 \\
\hline 4 & 349.2 & 1.5 & 910.3 & 967.7 & 1.5 \\
\hline 5 & 195.0 & 1.3 & 512.9 & 582.7 & 1.4 \\
\hline 6 & 435.3 & 0.8 & 1022.0 & 1094.3 & 1.8 \\
\hline 7 & 283.2 & 0.8 & 420.2 & 452.0 & 0.8 \\
\hline 8 & 186.0 & 0.5 & 330.3 & 390.3 & 1.2 \\
\hline 9 & 305.2 & 3.5 & 1210.3 & 1336.3 & 1.8 \\
\hline 10 & 416.4 & 1.3 & 1477.3 & 1601.0 & 2.2 \\
\hline 11 & 256.0 & 0.5 & 388.3 & 457.0 & 1.5 \\
\hline 12 & 624.4 & 0.8 & 1690.5 & 1845.9 & 2.6 \\
\hline 13 & 308.2 & 0.5 & 565.3 & 628.8 & 1.5 \\
\hline 14 & 520.7 & 0.5 & 991.6 & 1060.9 & 1.4 \\
\hline 15 & 117.0 & 3.5 & 427.0 & 577.5 & 2.7 \\
\hline 16 & 196.7 & 2.5 & 652.4 & 812.6 & 3.8 \\
\hline 17 & 203.0 & 3.5 & 908.0 & 969.9 & 1.5 \\
\hline Mean & 331.1 & 1.57 & 883.3 & 976.5 & 1.81 \\
\hline S.D. & 134.8 & 1.21 & 429.2 & 448.6 & 0.71 \\
\hline
\end{tabular}

Table 2. Comparison of pharmacokinetic parameters of Mirodenafil after administration of an oral $100 \mathrm{mg}$ to healthy volunteers from Mexico (this study) and Koreans [10]. Data are expressed as mean \pm S.D.

\begin{tabular}{ccc}
\hline Parameter & Mexicans (this study) & Koreans [10] \\
\hline $\mathrm{C}_{\max }(\mathrm{ng} / \mathrm{mL})$ & $331.1 \pm 134.8$ & $373.4 \pm 171.3$ \\
$\mathrm{t}_{\max }(\mathrm{h})$ & $1.57 \pm 1.21$ & $1.26 \pm 0.55$ \\
$\mathrm{AUC}_{\infty}(\mathrm{ng} \cdot \mathrm{h} / \mathrm{mL})$ & $976.5 \pm 448.6$ & $931.4 \pm 404.6$ \\
$\mathrm{t}_{1 / 2}(\mathrm{~h})$ & $1.81 \pm 0.71$ & $1.96 \pm 0.55$ \\
\hline
\end{tabular}

should not be blindy extrapolated between populations. Mirodenafil has demonstrated to be effective in the treatment of erectile dysfunction in Korean population establishing dosage regime that are effective and safe. As efficacy and safety in most of cases depend on plasma concentration reached after dosing, it is important to establish if interethnic differences in the pharmacokinetics of this drug exist. That is why, in this study we characterized the oral pharmacokinetics of Mirodenafil in Mex- 
icans and a comparison with the values reported in Koreans was performed. Since no important differences in the values obtained in both populations was observed, it is concluded that no pharmacokinetic differences for Mirodenafil are present and therefore, dosage recommendation should be similar for both populations. Notwithstanding, the main limitation of the present study is the absence of a parallel study between Mexicans and Koreans due the Korean pharmacokinetic data were based on observation of past studies, so future studies will be needed to address this issue. Furthermore, a study in dysfunction erectile patients will also be necessary for additional evaluation of safety and efficacy in Mexicans. Moreover, it is lacking a pharmacokinetic study in Caucasians in order to determine interethnic pharmacokinetic differences.

\section{REFERENCES}

[1] J. S. Paick, T. Y. Ahn, H. K. Choi, et al., "Efficacy and Safety of Mirodenafil, a New Oral Phosphodiesterase Type-5 Inhibitor for Treatment of Erectile Dysfunction,” Journal of Sexual Medicine, Vol. 5, No. 11, 2008, pp. 2672-2680.

http://dx.doi.org/10.1111/j.1743-6109.2008.00945.x

[2] C. C. Carson and T. F. Lue, "Phosphodiesterase Type 5 Inhibitors for Erectile Dysfunction,” BJU International, Vol. 96, No. 3, 2005, pp. 257-280.

http://dx.doi.org/10.1111/j.1464-410X.2005.05614.X

[3] J. D. Corbin and S. H. Francis, "Pharmacology of Phosphodiesterase-5 Inhibitors," International Journal of Clinical Practice, Vol. 56, No. 6, 2002, pp. 453-459.

[4] G. Lee, T. K. Kim and B.Y. Lee, "Pharmacokinetics of Mirodenafil, a New Erectogenic, and Its Metabolite, SK 3541, in Rats: Involvement of CYP1A1/2, 2B1/2, 2D Subfamily, and 3A1/2 for the Metabolism of Both Mirodenafil and SK3541," Journal of Pharmacy \& Pharmaceutical Sciences, Vol. 13, No. 1, 2010, pp. 93-106.

[5] H. Kim, D. W. Sohn, S. D. Kim, S. H. Hong, H. J. Suh, C. B. Lee and S. W. Kim, "The Effect of Mirodenafil on the Penile Erection and Corpus Cavernosum in the Rat Model of Cavernosal Nerve Injury," International Journal of Impotence Research, Vol. 22, No. 5, 2010, pp. 291-297. http://dx.doi.org/10.1038/ijir.2010.19

[6] S. K. Lee, Y. Kim, T. K. Kim, G. J. Im, B. Y. Lee, D. H. Kim, C. Jin and H. H. Yoo, "Determination of Mirodenafil and Sildenafil in the Plasma and Corpus Cavernous of SD Male Rats," Journal of Pharmaceutical and Biomedical Analysis, Vol. 49, No. 2, 2008, pp. 513-518. http://dx.doi.org/10.1016/j.jpba.2008.11.004

[7] Y. S. Lee, Y. H. Choi, S. Y. In, T. K. Kim, K. H. Ryu, B. Y. Lee and M. G. Lee, "Pharmacokinetics of Mirodenafil and Its Two Metabolites, SK3541 and SK3544, in Spontaneously or DOCA-Salt-Induced Hypertensive Rats," Biopharmaceutics \& Drug Disposition, Vol. 32, No. 1, 2011, pp. 38-49. http://dx.doi.org/10.1002/bdd.737

[8] B. S. Shin, S. K. Hu, J. Kim, J. G. Oh, W. N. Youn, B. Lee, K. A. Um, D. K. Kim, J. Y. Lee and S. D. Yoo, "Development of LC/MS/MS Assay for the Determination of 5-ethyl-2-\{5-[4-(2-Hydroxyethyl)Piperazine-1-Sulfonyl]-2-Propoxyphenyl \}-7-Propyl-3,5-Dihydropyrrolo [3, 2-d]Pyrimidin-4-One (SK3530) in Human Plasma: Application to a Clinical Pharmacokinetic Study," Journal of Pharmaceutical and Biomedical Analysis, Vol. 45, No. 1, 2007, pp. 176-184. http://dx.doi.org/10.1016/j.jpba.2007.06.021

[9] B. H. Kim, S. Jeong, J. W. Kim, K. Lim, K. P. Kim, B. Y. Lee, S. G. Shin, I. J Jang and K. S. Yu, "Influence of Alcohol on the Hemodynamic Effects and Pharmacokinetic Properties of Mirodenafil: A Single-Dose, RandomizedSequence, Open-Label, Crossover Study in Healthy Male Volunteers in Korea,” Clinical Therapeutics, Vol. 31, No. 12, 2009, pp. 1234-1243. http://dx.doi.org/10.1016/j.clinthera.2009.06.008

[10] K. H. Shin, B. H. Kim, T. E. Kim, J. W. Kim, S. J. Yi, S. H. Yoon, J. Y. Cho, S. G. Shin, I. J. Jang and K. S. Yu, "The Effects of Ketoconazole and Rifampicin on the Pharmacokinetics of Mirodenafil in Healthy Korean Male Volunteers: An Open-Label, One-Sequence, Three-Period, Three-Treatment Crossover Study," Clinical Therapeutics, Vol. 31, No. 12, 2009, pp. 3009-3020. http://dx.doi.org/10.1016/j.clinthera.2009.12.012

[11] G. Castañeda-Hernández, C. Hoyo-Vadillo, J. A. PalmaAguirre and F. J. Flores-Murrieta, "Pharmacokinetics of Oral Nifedipine in Different Populations," Journal of Clinical Pharmacology, Vol. 33, No. 2, 1993, pp. 140-145. http://dx.doi.org/10.1002/j.1552-4604.1993.tb03934.x

[12] J. A. Palma-Aguirre, J. González-Llaven, F. J. FloresMurrieta and G. Castañeda-Hernández, "Bioavailability of Oral Cyclosporine in Healthy Mexican Volunteers: Evidence for Interethnic Variability,” Journal of Clinical Pharmacology, Vol. 37, No. 7, 1997, pp. 630-634. http://dx.doi.org/10.1002/j.1552-4604.1997.tb04346.x

[13] L. Chávez-Teyes, G. Castañeda-Hernández and F. J. FloresMurrieta, "Pharmacokinetics of Midazolam in Mexicans: Evidence for Interethnic Variability,” Clinical Drug Investigation, Vol. 17, No. 3, 1999, pp. 233-239.

[14] F. J. Flores-Murrieta, G. Castañeda-Hernàndez, V. Granados-Soto and J. E. Herrera, "Increased Bioavailability of Sildenafil in Mexican Men,” JAMA, Vol. 283, No. 14, 2000, pp. 1825-1826. http://dx.doi.org/10.1001/jama.283.14.1825

[15] S. C. Chien, Y. S. Uang, H. Y. Lin and K. Y. Hsu, "Pharmacokinetics of Nifedipine in Taiwanese," Biopharmaceutics \& Drug Disposition, Vol. 25, No. 2, 2004, pp. 7784. http://dx.doi.org/10.1002/bdd.386 


\section{Abbreviations List}

AUC $\infty$ : Area under the concentration-time curve from zero to infinitum

$\mathrm{AUC}_{24 \mathrm{~h}}$ : Twenty-four-hour area under the concentrationtime curve

$\mathrm{C}_{\max }$ : Maximum plasma concentration

CYP3A4: Cytochrome P-450 3A4

GMPc: Cyclic guanosine monophosphate
HPLC: High performance liquid chromatography $\mathrm{K}_{\mathrm{e}}$ : Terminal elimination rate constant NO: Nitric oxide

PDE-5: 5-phosphodiesterase

S.D.: Standard deviation

$\mathrm{t}_{1 / 2}$ : Drug half-life

$t_{\max }$ : Time to maximum plasma concentration 